\title{
EFFECTS OF DICAMBA HERBICIDE ON TUBERCULARIA ULMEA CANKER DEVELOPMENT
}

\author{
by Marcus B. Jackson ${ }^{1}$ and Robert W. Stack ${ }^{2}$
}

\begin{abstract}
Dicamba (3,6-dichloro-o-anisic acid) herbicide was applied to the roots of potted Siberian elm (Ulmus pumila) and Russian-olive (Elaeagnus angustifolia) trees in a greenhouse. Five herbicide concentrations were used: equivalent to rates of 0 (0), 93 (1/12), 140 (1/8), $280(1 / 4)$, and 1,121 (1) g/ha (lb/ac) active ingredient. Two weeks after herbicide application, each tree was inoculated with a single isolate of the canker-causing fungus Tubercularia ulmea. The experiment was repeated using two different T. ulmea isolates. Leaf cupping, a symptom of dicamba exposure, was evident two to three weeks after herbicide application. Symptoms occurred at rates of $140 \mathrm{~g} / \mathrm{ha}$ (1/ $8 \mathrm{lb} / \mathrm{ac})$ and above in the Siberian elms and the 1,121 g/ha (1 $\mathrm{lb} / \mathrm{ac}$ ) rate in the Russian-olives. All four $T$. ulmea isolates caused cankers, with canker size differences between fungal isolates and between tree species. None of the herbicide treatments increased or decreased T. ulmea canker size.
\end{abstract}

Key Words. Disease; elm; Ulmus; Russian-olive; Elaeagnus.

In 1947, Carter described a canker and dieback of Siberian elm (Ulmus pumila) in Illinois, U.S. (Carter 1947). He identified and named Tubercularia ulmea as the fungus causing the stem canker disease of Siberian elm (Carter 1947). Tubercularia ulmea is generally believed to infect trees through physical injury to the bark (Sengpiel 1977). Injuries may be caused by freezing and other adverse weather conditions (Schoeneweiss 1981), insects and other animals, and human activities such as pruning, weed control, and harvesting of tree crops. In addition to entering through cracks in the bark caused by freezing, the fungus may enter through lenticels and leaf buds of frost-damaged woody plants (Grant and Spaulding 1939). Cankers caused by T. ulmea have inflicted considerable damage to Siberian elm, Russian-olive (Elaeagnus angustifolia), and honeylocust (Gleditsia triacanthos) tree plantings in North Dakota (Sengpiel 1977; Walla and Stack 1988). The fungus $T$. ulmea is widely recognized as a facultative pathogen of stressed trees, shrubs, and woody vines (Sengpiel 1977; Farr et al. 1989).
Many canker-causing fungi are facultative pathogens. Facultatively pathogenic fungi survive primarily as saprobes (decomposing dead organic matter) but act as pathogens (causing disease) when presented with a weakened host (Manion 1991). Among factors shown to increase canker size on stressed trees and shrubs are drought (Bier 1964), freeze injury (Schoeneweiss 1981), and root injury (Bedker and Blanchette 1983). In addition, herbicide exposure has been suggested as an important factor that predisposes trees to cankers (Otta and Bode 1972; Dooling 1973).

An herbicide may increase or decrease disease in a plant, depending on its interactions with the plant and the pathogen (Leela and Ganeshan 1993). Dooling (1973) noticed that cankers appeared to be more prevalent on trees in windbreaks that showed herbicide injury than in windbreaks without obvious herbicide injury. He expressed the opinion that "the connection between herbicide injury, cankers, and fungi is a professional opinion of the author based on nondetailed observations. This hypothesis needs further study for clarification." Otta (1974) reported that stem growth was significantly reduced and bark abnormalities occurred when Siberian elm was exposed to $2,4-\mathrm{D}$ concentrations of 10 and $25 \mathrm{mg} / \mathrm{L}$ (ppm), respectively. He concluded that the reduced growth caused by 2,4-D may have contributed to the decline of Siberian elm windbreaks in South Dakota. Walla and Stack (1987) reported results of a statewide survey of windbreak condition in North Dakota and found that windbreak trees were in poor condition. Stack et al. (1990) proposed herbicides among the predisposing factors for the poor condition when they applied Manion's “decline spiral" concept (Manion 1991) to decline of Siberian elm plantings on the U.S. Great Plains. Calkins and Swanson (1997) suggested that 'Skyline' honeylocust trees were more susceptible to Nectria cinnabarina cankers in nurseries when they were treated with the herbicide oxadiazon (3-[2,4-dichloro-5-(1-methylethoxy)phenyl]-5-(1,1dimethylethyl)-1,3,4-oxadiazol-2(3H)-one) than when 
they were grown with cover crops. The authors believed that the increased susceptibility was due to root injury caused by bare soil from the herbicide treatment and possibly due to interactions among the tree, the fungus, and the herbicide. We have received reports from city foresters in North Dakota and have observed several cases of herbicide injury associated with large cankers on urban trees.

Dicamba (3,6-dichloro-o-anisic acid) and 2,4-D (2,4dichlorophenoxyacetic acid) are two growth regulatortype herbicides commonly used to control broadleaf weeds in turfgrass around ornamental and shade trees. These postemergence herbicides are known to cause damage to landscape trees (Smith 1975). Of the two, dicamba has been shown to be more phytotoxic to shade trees (Neely and Crowley 1974). Differences in species sensitivity to herbicides have been shown by previous research (Sinclair et al. 1987). The following experiments were done to determine if a single exposure to dicamba herbicide would increase T. ulmea canker size on trees and ultimately increase the number of girdling cankers.

\section{MATERIALS AND METHODS Plant Materials and Culture}

Young Siberian elm and Russian-olive trees grown in pots were each inoculated with an isolate of the canker pathogen T. ulmea two weeks after they were exposed to dicamba herbicide. Bare-root seedlings were obtained from a tree nursery that produces stock for windbreak and other conservation uses. The Russian-olives for experiment 1 and all Siberian elms were two-year-old nursery stock. Due to the poor quality of two-year-old Russian-olive nursery stock available for experiment 2, one-year-old Russian-olive trees were used in that experiment. Trees were planted singly into artificial potting mix (Sunshine Mix \#2, Fisons Horticulture, Vancouver, BC) in 3-L plastic pots. Each $0.1 \mathrm{~m}^{3}$ $\left(3.5 \mathrm{ft}^{3}\right)$ of this planting mix was supplemented with $60 \mathrm{~mL}$ $(2 \mathrm{fl} \mathrm{oz})$ of a trace element fertilizer (Peters Micronutrient Formula, Scotts-Sierra Horticultural Products Company, Marysville, OH), $2.88 \mathrm{~L}$ (97.4 fl oz) 7-40-6 granular fertilizer (Magamp with K, W.R. Grace \& Co., Columbia, MD), and $720 \mathrm{~mL}(24.4 \mathrm{fl} \mathrm{oz})$ of crushed dolomitic limestone. The trees were grown in a greenhouse under a 16-hour photoperiod between $16^{\circ} \mathrm{C}\left(60^{\circ} \mathrm{F}\right)$ and $32^{\circ} \mathrm{C}\left(90^{\circ} \mathrm{F}\right)$. Plants were watered as needed and fertilized biweekly by applying $300 \mathrm{~mL}(10.1 \mathrm{fl} \mathrm{oz})$ water containing 15-16-17 soluble fertilizer (Peters, Scotts-Sierra Horticultural Products Co., Marysville, $\mathrm{OH}$ ) at a rate of $200 \mathrm{mg}$ nitrogen/L water $(200$ ppm) per plant.

\section{Herbicide Treatment}

The trees were grown for five weeks and three and one-half weeks before herbicide exposure for experiments 1 and 2, respectively. Prior to herbicide application, each pot was placed in its own plastic tray to prevent herbicide loss and cross-contamination during watering. Trees were treated with five rates of dicamba herbicide: $0 \mathrm{mg} /$ pot a.i. (active ingredient $)=0 \mathrm{~g} / \mathrm{ha}(0$ $\mathrm{lb} / \mathrm{ac}), 0.10 \mathrm{mg} /$ pot a.i. $=93 \mathrm{~g} / \mathrm{ha}(1 / 12 \mathrm{lb} / \mathrm{ac}), 0.14$ $\mathrm{mg} /$ pot a.i. $=140 \mathrm{~g} / \mathrm{ha}(1 / 8 \mathrm{lb} / \mathrm{ac}), 0.29 \mathrm{mg} /$ pot a.i. $=$ $280 \mathrm{~g} / \mathrm{ha}(1 / 4 \mathrm{lb} / \mathrm{ac})$, and $1.16 \mathrm{mg} /$ pot a.i. $=1,121 \mathrm{~g} / \mathrm{ha}$ (1 lb/ac). Approximately $102 \mathrm{~g} / \mathrm{ha}$ a.i. $(1 / 11 \mathrm{lb} / \mathrm{ac})$ to $187 \mathrm{~g} / \mathrm{ha}$ a.i. $(1 / 6 \mathrm{lb} / \mathrm{ac})$ is the recommended rate of dicamba for some lawn herbicides. The herbicide was applied to the soil-less growing medium in $200 \mathrm{~mL}$ $(6.8 \mathrm{fl} \mathrm{oz})$ of distilled water. After the herbicide solution had settled into the medium, an additional $250 \mathrm{~mL}$ $(8.5 \mathrm{fl} \mathrm{oz})$ of distilled water was applied to each pot to move the chemical into the root zone. Controls received $450 \mathrm{~mL}(15.3 \mathrm{fl} \mathrm{oz})$ of distilled water with no herbicide.

\section{Source of Fungal Cultures and Inoculum Production}

Wheat kernels colonized by T. ulmea isolates were used as inoculum. The isolates were collected from honeylocust (MJ069 and MJ232), Russian-olive (MJ141), and Siberian elm (MJ075) trees. Canker-causing ability varies between T. ulmea isolates (Jackson and Stack 1995); therefore, the isolates used for these experiments had been found to cause extensive cankers in previous studies (Jackson and Stack 2002). Wheat kernel inoculum was prepared by placing autoclaved wheat kernels on the surface of PDA (potato dextrose agar) in a Petri dish that was later inoculated with a T. ulmea isolate. The wheat kernel cultures were grown for two to five weeks before use.

\section{Inoculation and Experimental Design}

Two weeks after the herbicide treatments were applied, the main stem of each plant was inoculated with a wheat kernel colonized by one of two isolates of T. ulmeaMJ075 or MJ141 for experiment 1 and MJ069 or MJ232 for experiment 2. Each stem was wounded by slicing an inverted $\mathrm{V}$-notch wound, $5 \mathrm{~mm}$ (1/5 in.) wide by $8 \mathrm{~mm}$ $(1 / 3$ in.) long through the bark and vascular cambium, with a scalpel. Bending back the bark flap produced by the $\mathrm{V}$-notch cut exposed the sapwood. An infected wheat kernel was placed between the exposed sapwood and bark. The bark flap was pressed against the 
kernel, wrapped in Parafilm ${ }^{\circledR}$, and covered with aluminum foil. Experimental design was a randomized complete block design with one-tree plots and four replicate inoculations for each treatment $\times$ isolate combination on each tree species. The plants were returned to the greenhouse for four weeks.

\section{Data Collection and Analysis}

Presence of herbicide injury was determined (+ or - ) by visual inspection for leaf-cupping symptoms at the time of inoculation. To determine the extent of cankering, the bark on each stem was cut and removed. Discolored sapwood above and below the wound was measured and the two measurements were combined for analysis. Data for canker lengths were analyzed by analysis of variance using a general linear models computer software package (SuperAnova ${ }^{\circledR}$, Abacus Concepts, Berkeley, CA). The mean canker lengths for herbicide concentration, tree species, and fungal isolates were compared.

\section{RESULTS}

Two T. ulmea isolates were tested in the first experiment and two isolates were tested in the second experiment with similar results. In the first experiment, both T. ulmea isolates caused cankers on the trees, but MJ141 (mean = $22.2 \mathrm{~mm})$ produced significantly $(P=0.05)$ larger cankers than MJ075 (mean $=3.0 \mathrm{~mm})$. Significantly $(P=0.05)$ larger cankers were produced on Russian-olive (mean = $18.3 \mathrm{~mm}$ ) than on Siberian elm (mean $=6.9 \mathrm{~mm}$ ). In the second experiment, both isolates caused cankers on the trees, but MJ069 (mean $=44.6 \mathrm{~mm}$ ) produced significantly $(P=0.05)$ larger cankers than MJ232 (mean $=20.0$ $\mathrm{mm})$. There was no significant $(P=0.05)$ difference in the size of cankers produced on Siberian elm (mean $=35.1$ $\mathrm{mm})$ compared to those on Russianolive (mean $=29.6$ $\mathrm{mm})$ in the second experiment. Cankers in experiment 2 were substantially larger than those in experiment 1.

Two weeks after herbicide was applied in the first experiment, leaf cupping was apparent in $75 \%$ of the Russian-olives treated with 1,121 g/ha $(1 \mathrm{lb} / \mathrm{ac})$ dicamba and $95 \%$ of the Siberian elms treated with $140 \mathrm{~g} /$ ha $(1 / 8 \mathrm{lb} / \mathrm{ac})$ and above dicamba. Dieback occurred in $75 \%$ of the Siberian elms treated with 1,121 g/ha $(1 \mathrm{lb} / \mathrm{ac})$ dicamba. In the second experiment, no herbicide injury was apparent after two weeks. After three weeks, phytotoxicity symptoms were similar to the symptoms in the first herbicide experiment but were difficult to read due to canker-induced death of some trees.

Herbicide concentration had no significant $(P=$ 0.05) effect on canker size in either the first or second experiment (Table 1). Acute exposure to root-applied dicamba herbicide neither increased nor decreased T. ulmea canker development in either tree species.

\section{DISCUSSIONS AND CONCLUSIONS}

The most important information gained from these experiments is that acute herbicide exposure did not have as direct of an effect on canker development as was demonstrated for moisture stress (Bier 1964), freeze injury (Schoeneweiss 1981), and root injury (Bedker and Blanchette 1983). These findings do not support the idea that dicamba herbicide exposure increases canker development, as Otta and Bode (1972) suggested for 2,4-D. However, these experiments examined only short-term exposure of two tree species to dicamba followed soon after by inoculations with the canker fungus. The chronic effects that long-term exposure of dicamba may have on canker development and the effects that other herbicides have on T. ulmea canker development are not well known. The physiological responses of nontarget plant species to many herbicides are not as well studied as for target (weed) plants or crops. Perennial woody plants, in particular, may be affected in a different manner than short-lived, herba-
Table 1. Canker length ( $\mathrm{mm})$ means on Siberian elm and Russian-olive trees inoculated with Tubercularia ulmea isolates two weeks after treatment with five concentrations of dicamba herbicide

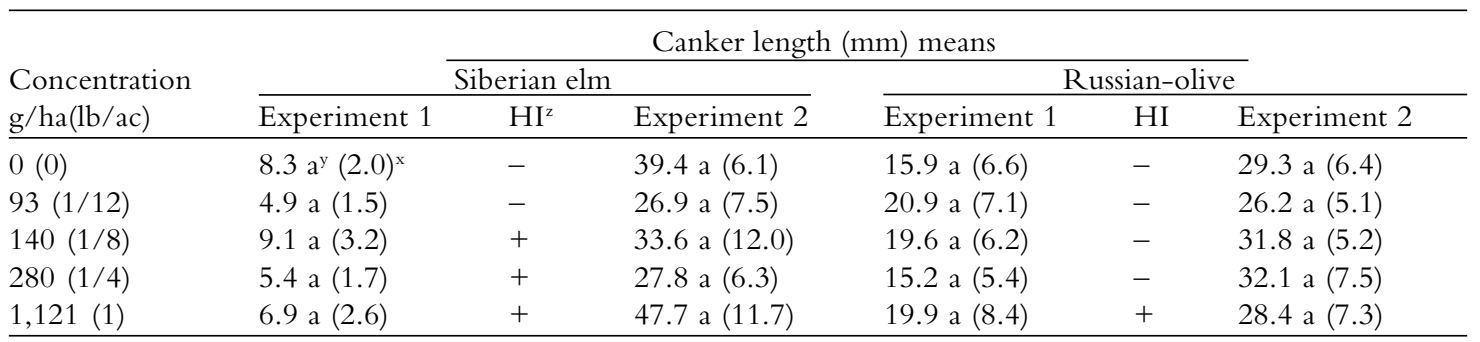

${ }^{2} \mathrm{HI}=$ herbicide injury $(+=$ leaf cupping evident,$-=$ no leaf cupping evident $)$.

${ }^{\mathrm{y}}$ Mean separation in each column by Fishers Protected LSD $(P=0.05)$.

x Standard error.

Values are means of four replicates of two isolates combined. 
ceous plants. Furthermore, interactions between herbicides and other stress factors such as moisture stress and freeze damage may play a role in canker development and should be investigated.

While the hypothesis that dicamba may predispose trees to cankers remains unproven, direct herbicide injury to trees was observed, as is well-documented, and remains a concern (Neely and Crowley 1974). Tissues killed by herbicides would likely serve as good substrates for saprophytic growth of T. ulmea to increase inoculum loads and may also serve as entry points for infections. In addition, it is important to determine if bark deformed by an herbicide serves as an entrance site for canker fungi.

\section{LITERATURE CITED}

Bedker, P.J., and R.A. Blanchette. 1983. Development of cankers caused by Nectria cinnabarina on honey-locust after root pruning. Plant Dis. 67:1010-1013.

Bier, J.E. 1964. The relation of some bark factors to canker susceptibility. Phytopathology 54:250-253.

Calkins, J.B., and B.T. Swanson. 1997. Susceptibility of 'Skyline' honeylocust to cankers caused by Nectria cinnabarina influenced by nursery field management system. J. Environ. Hortic. 15:6-11.

Carter, J.C. 1947. Tubercularia canker and dieback of Siberian elm (Ulmus pumila L.). Phytopathology 37:243-246.

Dooling, O.J. 1973. Cankers in North Dakota Windbreak Plantings: Survey and Evaluation. Insect and Disease Report, USDA Forest Service/Northern Region, Report No. 73-10. Missoula, MT. 6pp.

Farr, D.F., G.F. Bills, G.P. Chamuris, and A.Y. Rossman. 1989. Fungi on Plants and Plant Products in the United States. APS Press, St. Paul, MN. 1252 pp.

Grant, T.J., and P. Spaulding. 1939. Avenues of entrance for canker-forming Nectrias of New England hardwoods. Phytopathology 29:351-358.

Jackson, M.B., and R.W. Stack. 1995. Pathogenic variation among isolates of Tubercularia causing cankers of woody plants. Phytopathology 85:1044.

Jackson, M.B., and R.W. Stack. 2002. Tubercularia ulmea canker: Effect of pathogen, host, and cultural practice. Bull. Finn. For. Res. Inst. (accepted for publication).

Leela, D., and G. Ganeshan. 1993. Herbicides and plant disease interactions: A review. Adv. Hortic. For. 3:1-48.
Manion, P.D. 1991. Tree Disease Concepts (2nd ed.). PrenticeHall, Englewood Cliffs, NJ. 402 pp.

Neely, D., and W.R. Crowley. 1974. Toxicity of soil-applied herbicides to shade trees. HortScience 9:147-149.

Otta, J.D. 1974. Effects of 2,4-D herbicide on Siberian elm. For. Sci. 20:287-290.

Otta, J.D., and F.L. Bode. 1972. Siberian elm cankers in South Dakota. Plant Dis. Rep. 56:572-574.

Schoeneweiss, D.F. 1981. Infectious diseases of trees associated with water and freezing stress. J. Arboric. 7:13-18.

Sengpiel, H.W. 1977. Tubercularia Canker: A Problem on Highway Plantings in North Dakota. Internal publication, North Dakota State Highway Department, Bismarck, ND.

Sinclair, W.A., H.H. Lyon, and W.T. Johnson. 1987. Diseases of Trees and Shrubs. Comstock Publishing Associates, Ithaca, NY. 575 pp.

Smith, E.M. 1975. Tree stress from salts and herbicides. J. Arboric. 1:201-205.

Stack, R.W., J.M. Krupinsky, and J.A. Walla. 1990. Decline of Siberian elm on the Great Plains (abstract). Phytopathology 80:1064.

Walla, J.A., and R.W. Stack. 1987. An evaluation of the condition of twelve common windbreak species in North Dakota. Proc. North Dakota Acad. Sci. 41:55.

Walla, J.A., and R.W. Stack. 1988. Tubercularia canker of honey-locust in North Dakota. Plant Dis. 72:734.

Acknowledgments. The authors thank Dr. John Nalewaja for his advice in designing the experiments and Greg Morgensen, manager of Lincoln-Oakes Nurseries, for donating the Russian-olive and Siberian elm trees.

${ }^{1 *}$ Former Graduate Student, Plant Pathology Department, North Dakota State University

Currently Plant Pathologist, Northern Region

Forest Health Protection

USDA Forest-Service

200 E. Broadway

Missoula, MT 59807, U.S.

${ }^{2}$ Professor of Plant Pathology

Plant Pathology Department

North Dakota State University

Fargo, ND 58105, U.S.

${ }^{*}$ Corresponding author 
Résumé. Du dicamba (acide 3,6-dichloro-2methoxybenzoïque), un herbicide, a été appliqué sur les racines d'ormes de Sibérie (Ulmus pumila) et d'oliviers de Bohème (Elaeagnus angustifolia) empotés dans une serre. Cinq concentrations d'herbicides ont été utilisées, soient équivalentes à des taux de 0 (0), 93 (1/12), 140 (1/8), $280(1 / 4)$ et 1121 (1) g/ha (lb/ac) d'ingrédients actifs. Deux semaines après l'application des herbicides, chaque arbre a été inoculé avec une sélection isolée de champignon de Tubercularia ulmea qui cause un chancre. L'expérience a été répétée en utilisant deux isolations différentes de T. ulmea. Le recourbement des feuilles, un symptôme d'exposition au dicamba, était évident deux ou trois semaines après l'application d'herbicide. Les symptômes se produisaient à des taux de $140 \mathrm{~g} / \mathrm{ha}$ et plus pour les ormes de Sibérie, et à des taux de $1121 \mathrm{~g} / \mathrm{ha}$ pour les oliviers de Bohème. Les quatre isolations de T. ulmea causaient des chancres de différentes dimensions selon les diverses sélections de champignon et selon les espèces d'arbres. Aucun des traitement à l'herbicide n'a accrû ou décrû la dimensions des chancres causés par T. ulmea.

Zusammenfassung. In einem Gewächshaus wurden den Wurzeln von getopften Sibirischen Ulmen und Russischen Oliven das Herbizid Dicamba appliziert. Es wurden fünf Herbizidkonzentrationen benutzt: entsprechen der Rate von $0(0)$, 93 (1/12), 140 (1/8), 280 (1/4) und 1,121 (1) g/ha (lb/ac) von den aktiven Inhaltstoffen. Zwei Wochen nach der Herbizidbehandlung wurde jeder Baum in einem einzigen Isolat des Krebs verursachenden Pilzes inokuliert. Das Experiment wurde mit zwei verschiedenen isolaten wiederholt. Das Blattdrehen, ein Symptom der Dicamba-Behandlung erschien zwei bis drei Wochen nach der Applikation. Die Symptome erschienen in Ulmen bei Applikationsraten von $140 \mathrm{~g} / \mathrm{ha}(1 / 8 \mathrm{lb} / \mathrm{ac})$ und darüber und bei 1,121 g/ha(1 lb/ac) Raten in der Olive. Alle vier Krebsisolate verursachten Krebs mit unterschiedlichen Größenentwicklungen zwischen den Pilzisolaten und den Baumarten. Keine der Herbizidbehandlungen vergrößerte oder verkleinerte die Krebsgröße.

Resumen. Fue aplicado el herbicida Dicamba (3,6-dichloroo-anisic acid) a las raíces de árboles de olmo siberiano (Ulmus pumila) y olivo ruso (Elaeagnus angustifolia) en un invernadero. Se usaron cinco concentraciones de herbicida: equivalentes a tasas de 0 (0), 93 (1/12), 140 (1/8), 280 (1/4), and 1,121 (1) g/ha (lb/ ac) de ingrediente activo. Dos semanas después de la aplicación del ingrediente activo, cada árbol fue inoculado con una solución del aislamiento del hongo causante de cancro Tubercularia ulmea. El experimento fue repetido usando dos diferentes soluciones de T. ulmea. El bronceado de la hoja, un síntoma de la exposición a dicamba, fue evidente dos a tres semanas después de la aplicación del herbicida. Los síntomas ocurrieron a tasas arriba de $140 \mathrm{~g} / \mathrm{ha}(1 / 8 \mathrm{lb} / \mathrm{ac})$ en los olmos siberianos y la tasa de 1,121 g/ha (1 lb/ac) en los olivos de Rusia. Todos los aislamientos causaron cancros, con diferencias en el tamaño del cancro entre aislamientos y entre especies. Ninguno de los tratamientos incrementó o disminuyó el tamaño del cancro T. ulmea. 